\title{
The Effect of Farmers' Entrepreneurial Behavior on Business Performance of PUAP Program in Pandawai Sub-district, East Sumba Regency
}

\author{
Elsa Christin Saragih ${ }^{1 *}$, Tinjung Mary Prihtanti ${ }^{2}$ and Yuliawati $^{2}$ \\ ${ }^{1}$ Magister of Agroecotechnology, Faculty of Agriculture and Business, \\ Satya Wacana Christian University, Salatiga, Indonesia; ${ }^{2}$ Department of Agribusiness, \\ Faculty of Agriculture and Business, Satya Wacana Christian University, Salatiga, Indonesia \\ ${ }^{*}$ Corresponding author: elsacsaragih@gmail.com
}

\begin{abstract}
Rural Agribusiness Development (PUAP) was a program for poverty alleviation among farmers through capital assistance with entrepreneurship training. This study were aimed to determine: (1) the effect of internal factors, Gapoktan dynamics and supporting factors of the PUAP program on farmers' entrepreneurial behaviors and (2) the effect of farmers' entrepreneurial behavior on the farmers' business performance whose received PUAP programs. This research was conducted in Pandawai subdistrict, East Sumba regency. Data were obtained from 115 farmers respondent who received PUAP funds, that had been selected by simple random sampling technique. Parameter estimation procedures were carried out with the Structural Equation Model (SEM) analysis approach by using AMOS 24 software. The result showed that the internal factors of PUAP recipient farmers had a positive yet not significant effect on entrepreneurial behavior, while the dynamics of Gapoktan and the supporting factors of PUAP program positively and significantly influenced farmers' entrepreneurial behavior. Entrepreneurial behavior had positive and significant effect on business performance. Thus, by increasing the entrepreneurial behavior, it will improve the business performance of farmers who received the PUAP programs in Pandawai sub-district.
\end{abstract}

Keywords: entrepreneurial behavior, farmers' internal factors, Gapoktan dynamics, PUAP, SEM

Cite this as: Saragih, E. C., Prihtanti, T. M., \& Yuliawati. (2019). The Effect of Farmers' Entrepreneurial Behavior on Business Performance of PUAP Program in Pandawai Sub-district, East Sumba Regency. Caraka Tani: Journal of Sustainable Agriculture, 34(1), 43-54. doi: http://dx.doi.org/10.20961/carakatani.v34i1.27714

\section{INTRODUCTION}

The issue of poverty still becomes a major problem for many developing countries, including Indonesia. The percentage of poor people in urban areas in Indonesia was 7.02\% in March 2018, while in rural areas was $13.20 \%$ (BPS, 2018). According to these data, it can be seen that the poverty in Indonesia were concentrated in rural areas, where most of the people work in the agricultural. In addition to farmers' inability to finance and access to capital sources, poverty in rural areas is also very closely related to the low quality of human resources and lack of entrepreneurship (Firdaus, 2014; Naminse and Zhuang, 2018). Understanding the relationship between poverty and entrepreneurship is significant in an attempt to revise the policies which are designed to improve the economy of a country. Farmers who are lack of entrepreneurial behavior always have difficulties in productively managing and developing business diversification in the midst of the abundant potential of local resources around their surrounding (Dumasari, 2014).

The idea that there is a connection between entrepreneurship and poverty had attracted attention of many researchers in the past few

\footnotetext{
* Received for publication February 7, 2019

Accepted after corrections March 13, 2019
} 
decades, so that in some countries poverty alleviation programs were conducted by using entrepreneurial approach. In Indonesia, entrepreneurship-based poverty alleviation programs had also been launched. In 2008, the Ministry of Agriculture implemented Rural Agribusiness Development (Pengembangan Usaha Agribisnis Perdesaan, PUAP) program. $P U A P$ is an agricultural development policy program designed to empower the farmers and reduce poverty and unemployment in rural areas. $P U A P$ program is implemented by providing an assistance of venture capital for members of farmer groups; whether it is farmer owners, sharecroppers, farm laborers and farm households, which are coordinated by the Farmer Group Association (Gabungan Kelompok Tani, Gapoktan) and accompanied by extension agents as well as farmer partner supervisor (Kementerian Pertanian, 2008). Based on the basic pattern of the implementation of PUAP program, entrepreneurship education and training is one of the main programs for Gapoktan. In this case, entrepreneurial factors are seen as highly significant aspect to apply to the community in achieving the goal of PUAP program to alleviate poverty.

East Sumba was one of the regencies that received PUAP program since 2008 with revolving funding allocation up to Rp 3 billion that had been given to 30 Gapoktan in 22 subdistricts with an allocation of Rp 100 million for each Gapoktan. In 2015, the number of Gapoktan in East Sumba regency that received revolving funds from the PUAP program had reached 134 Gapoktan with a total budget of Rp 13.4 billion (Table 1). Pandawai sub-district was one of the recipients of the PUAP program in East Sumba regency with seven Gapoktan in each village and urban village that had received the revolving fund.

Table 1. The number of Gapoktan recipients of PUAP program funds in East Sumba Regency in $2008-2015$

\begin{tabular}{lrrrrrrrrr}
\hline \multirow{2}{*}{ Description } & \multicolumn{8}{c}{ Year } & \multirow{2}{*}{ Total } \\
\cline { 2 - 9 } & 2008 & 2009 & 2010 & \multicolumn{1}{c}{2011} & 2012 & 2013 & 2014 & 2015 & \\
\hline Number of Gapoktan & 30.0 & 20.0 & 33.0 & 15.0 & 4.0 & 9.0 & 9.0 & 9.0 & 134.0 \\
$\begin{array}{l}\text { Ammount of distribution } \\
\text { of funds (billion Rupiah) }\end{array}$ & 3.0 & 2.0 & 3.3 & 1.5 & 0.4 & 0.9 & 0.9 & 0.9 & 13.4 \\
\hline
\end{tabular}

Source: BP4K Sumba Timur, 2016

An analysis of farmer business performance in implementing a program, such as PUAP, is needed to provide feedback on the extent of the program's success. Priyanto (2005) stated that entrepreneurship could had a direct effect on business performance, in which the entrepreneurial attitudes within farmers that were supported by extensive and adequate knowledge to do business and the ability and expertise of farmers in applying cultivation techniques, finance and marketing results, would increase productivity of his business and achieve higher prices. Before, Delmar (1996) had described the general model of the relationship between entrepreneurial behavior and business performance. The model consists of 4 main components, namely individuals (internal factors), environment, entrepreneurship and performance. Darmadji (2016) then added entrepreneurial behavior of farmers as a new variable that determined farming business performance. The application of entrepreneurial behavior to farmers was expected to improve their business performance, which eventually improved the farmers' welfare (Darmadji, 2016).

Entrepreneurial behavior of farmers is influenced by various determinant factors, both internal and external. According to Dirlanudin (2010) and Zainura et al. (2017), internal factors that influenced farmers' entrepreneurial behavior were the individual characteristics of farmers themselves, which were measured by education, experience, cosmopolitan, motivation of farming and the farmers' perception on the farming business they were run. Several external factors that influenced entrepreneurial behavior include financial support, government (policies and programs), education and training, business infrastructure and professionals, access to physical infrastructure, as well as cultural and social norms (Ximenes, 2014). In the implementation of the PUAP program, Gapoktan is a farmer institution that is directly related to and closest to farmers. Based on the research conducted by Hafinuddin et al. (2013), the Gapoktan dynamics had a positive and significant 
relationship to the success of the implementation of the PUAP program, in which the higher the dynamics of Gapoktan was, the higher the success rates of the PUAP program would be. The implementation of the PUAP program is accompanied by assistance and counseling that may improve the ability of farmers to manage their business. The implementation of the PUAP program can be supported by the availability of adequate supporting factors. For example, the government provides a good role in providing facilities for farmers in production, marketing their farm products and also infrastructures such as adequate access to road and market (Nindatu, 2012).

Various studies had been conducted on the implementation of the PUAP program in many regions, in which some of them examined the effectiveness of the PUAP program (Caesarion et al., 2013), the role of PUAP on the performance of Gapoktan (Hermawan et al., 2015), the impact of PUAP on income and business performance (Setiaji and Waridin, 2014), the success rate of the PUAP program (Supardi et al., 2015) and evaluated of the PUAP program (Nugrohoet al., 2018). However, there had not been many studies focused on entrepreneurial behavior of recipient farmers of PUAP, especially related to the performance of farming. So far, the aspects of farming performance in implementing the PUAP program were mostly related to the effectiveness of implementation and institutional aspects of Gapoktan. Therefore, the primary motivation of this research is to provide evidence whether the aspects of farmer entrepreneurial behavior can be an option as another approach in an attempt to improve farming performance in the implementation of the PUAP program. This study aimed to: (1) analyze the effect of internal factors, dynamics of Gapoktan and supporting factors of the PUAP program on entrepreneurial behavior of recipient farmer of PUAP programs in Pandawai sub-district and (2) analyze the effect of entrepreneurial behavior on the business performance of recipient farmers in Pandawai sub-district.

\section{MATERIALS AND METHOD}

\section{Location and time of study}

This research was conducted in Pandawai subdistrict, East Sumba regency. The selection process of research locations was executed purposively. The sub-district was selected due to the reason that it was one of the sub-districts that received PUAP programs in East Sumba Regency. Since the beginning of the PUAP program in 2008 until 2015 there were seven Gapoktan in each villages that had received the revolving fund, namely Mitra Sejati (Kadumbul) anda Li (Kambata Tana), Lata Luri (Maubokul), Kata Hamu Ndaba (Kawangu), Maju Bersama (Watumbaka), Marangga Monung (Palakahembi) and Nduma Luri (Laindeha). The research data collection was carried out from April to June 2018.

\section{Sampling technique}

The population in this study were all members of the Gapoktan who received PUAP fund in each villages in Pandawai, amounting to 857 farmers. The data in this study were would be analyzed using the SEM (Structural Equation Model) method with AMOS 24 software. In the SEM method, the number of suitable samples was between 100 up to 200 and the number of samples was at least 5 times the number of indicator variables (Ferdinand, 2014). So, because the number of indicators to be examined were 23 indicators, thus the number of samples taken ware 115 respondents. The sample was choosed by simple random sampling with an even distribution of proportions based on the number of farmers who received the PUAP program in each villages.

\section{Variable and measurement}

The variables used in this research included exogenous and endogenous latent variables, as well as manifest variables which can be seen fully in Table 2. The measurement of these variables was done through data collection used closed interview method with questionnaires. The questionnaire used Likert scale for level of approval from strongly disagree to strongly agree with assessment range 1-5.

\section{Statistical analysis}

This study is an explanatory research with quantitative approach. Explanatory research is a type of research that intends to explain the position of the examined variables and the causal relationships between these variables through hypotheses testing (Sugiyono, 2013). The data analysis technique was carried out with multivariate analysis using Structural Equation Model (SEM) analysis operated through IBM AMOS 24 to determine the effect of internal 
factors, the dynamics of Gapoktan and the supporting factors of the PUAP program on business performance through entrepreneurial behavior as an intervening variable. There are several steps that must be done to examine the model and hypothesis using SEM method (Ferdinand, 2014; Ghozali, 2017). These steps are: (1) developing a theoretical model that refers to the development of models through literature review, (2) developing flowcharts to see the causality relationships that is going to be examined, in which the results are presented in Figure 1, (3) converting the model specifications into a series of structural equations and (4) conducting a goodness of fit test, which includes: (i) assumption tests (normality, outliers and non multicollinearity) and (ii) goodness of fit (GOF) criteria test using various index to measure the degree of conformity between the model and the data presented.

Table 2. Latent and manifest/indikator variables of structural equation model

\begin{tabular}{lll}
\hline & Latent variable & \multicolumn{1}{c}{ Manifest variable (indicator) } \\
\hline Endogenous & Internal factors (f1) & 1. Education (X11) \\
& & 2. Experience (X12) \\
& & 3. Business Scale (X13) \\
& 4. Cosmopolitan (X14) \\
& 5. Motivation of farming (X15) \\
& 6. Perception on farming (X16) \\
\cline { 2 - 3 } & Dynamics of Gapoktan & 1. Goals of Gapoktan (X21) \\
& & 2. Structure of Gapoktan (X22) \\
& & 3. Solidarity (X23) \\
& & 4. Leadership (X24) \\
& & 5. Task function (X25) \\
& 6. Training and development (X26) \\
\cline { 2 - 3 } & Supporting factors of PUAP & 1. Assistance and counseling (X31) \\
& program (X3) & 2. Availability of production facilities (X32) \\
& & 3. Access to market information (X33) \\
& 4. Transportation facilities (X34) \\
\hline Exogenous & Entrepreneurial behavior (y1) & 1. Knowledge (Y11) \\
& & 2. Attitude (Y12) \\
& & 3. Skill (Y13) \\
\cline { 2 - 3 } & Business performance (Y2) & 1. Increased income (Y21) \\
& & 2. Expansion of the marketing area (Y22) \\
& & 3. Competitive advantage (Y23) \\
& & 4. Business endurance (Y24)
\end{tabular}

Source: Priyanto (2005); Dirlanudin (2010); Puspitaningsih (2016); Zainura (2016)

\section{RESULTS AND DISCUSSION}

\section{Implementation of rural agribusiness development (PUAP) program in Pandawai Sub-district}

The PUAP program in Pandawai sub-district, East Sumba regency was carried out in six villages and one urban village. Those villages are Kambatatana, Kadumbul, Moubokul, Watumbaka, Palakahembi, Laindeha and Kawangu (Table 3) since 2018. Based on the interview results with the head of Agricultural, Fishery and Foresty Center (Balai Penyuluhan
Pertanian Perikanan dan Kehutanan, BP3K) of Pandawai, Gapoktan which were appointed as the recipient of PUAP funds in 2008, received funding in early 2009 . Until 2015 , they were 7 Gapoktan or villages that received the PUAP program in each villages in Pandawai sub-district. Disbursement of PUAP funds was carried out in accordance to the general guidelines of PUAP program implementation, which was directly transferred to Gapoktan account in amount of Rp100 million. Thus, the total amount of funds that have been distributed to Pandawai sub-district was Rp700 million. 
Table 3. Gapoktan recipients of PUAP program funds in Pandawai Sub-district

\begin{tabular}{cllcl}
\hline No. & $\begin{array}{c}\text { Village/urban } \\
\text { Village }\end{array}$ & \multicolumn{1}{c}{ Gapoktan } & $\begin{array}{c}\text { Year received } \\
\text { PUAP funds }\end{array}$ & \multicolumn{1}{c}{ Type of business } \\
\hline 1. & Kadumbul & Mitra Sejati & 2008 & Cultivation of plants and farms \\
2. & Kambata Tana & Anda Li & 2008 & Cultivation of plants and farms \\
3. & Maubokul & Lata Luri & 2008 & $\begin{array}{l}\text { Cultivation of plants and farms } \\
\text { 4. }\end{array}$ \\
Kawangu & Kata Hamu Ndaba & 2008 & $\begin{array}{l}\text { Cultivation of plants and farms } \\
\text { and micro business }\end{array}$ \\
5. & Watumbaka & Maju Bersama & 2010 & Cultivation of plants and farms \\
6. & Palakahembi & Marangga Monung & 2011 & Cultivation of plants and farms \\
7. & Laindeha & Nduma Luri & 2015 & Farms \\
\hline
\end{tabular}

Source: $B P 3 K$ Pandawai, 2016

The fund management of the PUAP program in Pandawai is a savings and loan program with interest rates and return times agreed by the group. Farmer group association (Gapoktan) administrators and farmer group (Kelompok Tani, Poktan) administrators, accompanied by farmer partner supervisor (Penyelia Mitra Tani, PMT) officers, supervise the use of funds by member farmers (borrowers). This procedure was intended to ensure that funds are used properly by farmers. Gapoktan administrators also ensure the return of the loan is in accordance with the agreed time limit. Gapoktan administrators have to remind farmers to pay back their loan as well as the interest, before the deadline. The interest agreed by each Gapoktan generally ranges from $1.5 \%$ $2 \%$ per loan period. If there is a delay in refund, an agreed fine will be imposed.

\section{Goodness of fit test}

Evaluation of the normality test was conducted by looking at the skewness critical ratio (c.r) value of \pm 2.58 at the significance level of 0.01 . If there is a c.r. value greater than the critical value, it can be concluded that the data is not normally univariate. Meanwhile, the multivariate c.r. value can be seen on c.r. value in the last line with the same conditions (Ferdinand, 2014). The multivariate c.r. value is 0.533 , which means that the value is below the limit of the determined c.r. value. Therefore, the data in this study are normally distributed multivariately and it can be concluded that the data can be analyzed using Structural Equational Modeling (SEM).

Analysis of multivariate outliers was carried out by observing the Malhalanobis Distance criteria at the level of $1 \%$. The distance of the Mahalonobis was evaluated using Chi-square $\left(\chi^{2}\right)$ at the free degree of the number of variables used in the study (Bahri and Zamzam, 2014; Ferdinand, 2014). From the results of the data, the highest value of Mahalanobis d-squared by the respondent number 112 is 39.099 and the smallest value of Mahalanobis d-squared is by respondent number 78 with value of 16.873 . While based on the existing calculation, the limit of Mahalonobis distance value must be less than the value of $\chi^{2}$, that is 42.72829 . Thus, it can be concluded that the respondent's data has an Mahalonobis dsquared value $<$ value of $\chi^{2}$ (42.72829). Hence, the display of data from this analysis concludes that there are no multivariate outliers.

Multicollinearity testing was conducted using the output determinant of the covariance matrix. According to Tabanick Fidell in Ferdinand (2014), the very small value of the covariance matrix determinant indicates a multicollinearity or singularity problem. Based on the results of the AMOS test, it was found that the determinant of the covariance matrix is valued of 51105487.972 and this value is very far above zero. Therefore, it can be concluded that there is no evidence of multicollinearity or singularity in the combination of data used in this study, thus it can be further analyzed.

The structural goodness of fit test was carried out by evaluating the overall conformity model with the Goodnes of Fit measure. Evaluation of the overall goodness of fit test was done using several measures, such as statistic chi square, Root Mean Square Error of Approximation (RMSEA), Goodness of Fit Index (GFI), Adjusted Goodness of Fit Index (AGFI), Tucker Lewis Index (TLI) dan Comparative Fit Index (CFI). The summary of Goodness of Fit conformity can be seen in Figure 1 and Table 4. 


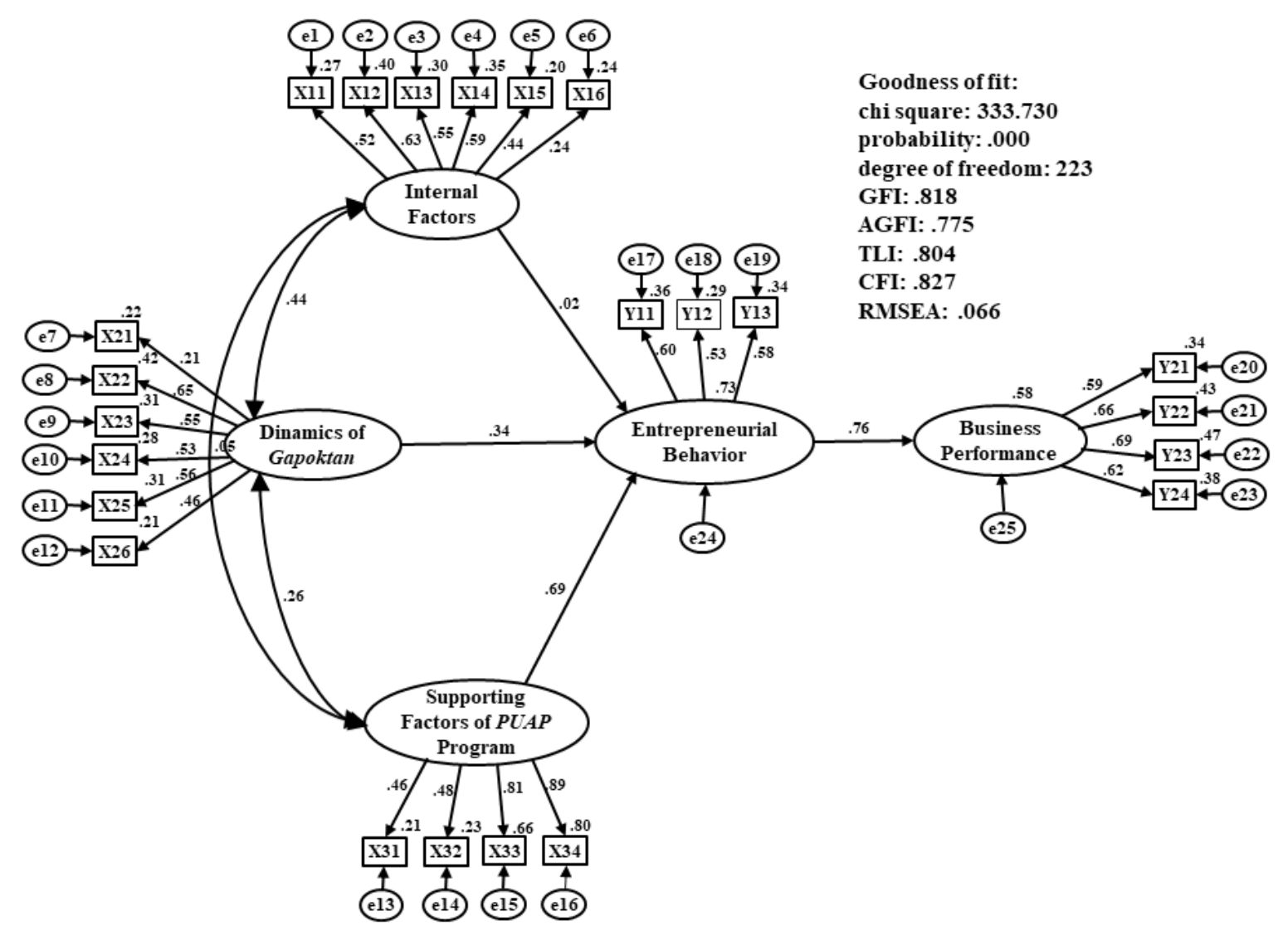

Figure 1. Full analysis of SEM

(Source: Primary Data Analysis, 2018)

Table 4. Feasibility test results of full model SEM

\begin{tabular}{|c|c|c|c|}
\hline $\begin{array}{l}\text { Goodness of } \\
\text { fit indices }\end{array}$ & Cut off value & $\begin{array}{c}\text { Model } \\
\text { test result }\end{array}$ & Category \\
\hline Chi Square & $\begin{array}{l}\text { Little } \\
\text { Value of } \chi^{2} \text { seen from df: } 223 ; \mathrm{p}: 5 \%=258.86\end{array}$ & 333.730 & Marginal fit \\
\hline Probabilitas & $\geq 0.05$ & 0.000 & Marginal fit \\
\hline CMIN/DF & $\leq 2.00$ & 1.497 & Good fit \\
\hline RMSEA & $\begin{array}{l}\text { RMSEA } \leq 0.05(\text { Close Fit }) \\
\text { RMSEA } \leq 0.08(\text { Good Fit })\end{array}$ & 0.066 & Good fit \\
\hline GFI & $\begin{array}{l}\text { GFI } \geq 0.90(\text { Good Fit }) \\
0.8 \leq \text { GFI }<0.90 \text { (Marginal Fit })\end{array}$ & 0.818 & Marginal fit \\
\hline AGFI & $\begin{array}{l}\text { AGFI } \geq 0.90(\text { Good Fit }) \\
0.8 \leq \text { AGFI }<0.90 \text { (Marginal Fit })\end{array}$ & 0.775 & Marginal fit \\
\hline TLI & $\begin{array}{l}\text { TLI } \geq 0.90(\text { Good Fit }) \\
0.8 \leq \mathrm{TLI}<0.90 \text { (Marginal Fit })\end{array}$ & 0.804 & Marginal fit \\
\hline CFI & $\begin{array}{l}\mathrm{CFI} \geq 0.90(\text { Good Fit }) \\
0.8 \leq \mathrm{CFI}<0.90(\text { Marginal Fit })\end{array}$ & 0.827 & Marginal fit \\
\hline
\end{tabular}

Based on Table 4, it can be seen that not all criteria showed the model asa good model. The CMIN / DF value of 1.479 shows a good structural equation model. The RMSEA measurement index is 0.066 which is in the range of expected value, $\leq$
0.08. Even though the chi-square, probability, AGFI, TLI and CFI have not fulfilled the value of good fit, however the conformity level of it is in marginal fit and the model obtained does not need to be modified again. Marginal value is a 
condition of the goodness of fit measure is below the absolute fit and incremental fit criteria, but still possible to continue on further analysis because it is close to the good fit criteria (Haryono, 2017).

\section{Measurement model}

The measurement model is intended to examine the indicators that form the variables. Measurement of loading factor values is carried out by looking at the estimated value on standardized regression weight output of SEM Amos analysis.

Table 5. Loading factor value (standardized regression weight)

\begin{tabular}{lclc}
\multicolumn{1}{c}{ Indicator } & & \multicolumn{1}{c}{ Variable } & Estimate \\
\hline Education (X11) & $\leftarrow$ & Internal factors & 0.517 \\
Experience (X12) & $\leftarrow$ & Internal factors & 0.633 \\
Business Scale (X13) & $\leftarrow$ & Internal factors & 0.547 \\
Cosmopolitan (X14) & $\leftarrow$ & Internal factors & 0.593 \\
Motivation of farming (X15) & $\leftarrow$ & Internal factors & 0.444 \\
Perception on farming (X16) & $\leftarrow$ & Internal factors & 0.495 \\
Goals of Gapoktan(X21) & $\leftarrow$ & Dynamics of Gapoktan & 0.470 \\
Structure of Gapoktan(X22) & $\leftarrow$ & Dynamics of Gapoktan & 0.652 \\
Solidarity (X23) & $\leftarrow$ & Dynamics of Gapoktan & 0.552 \\
Leadership (X24) & $\leftarrow$ & Dynamics of Gapoktan & 0.527 \\
Task function (X25) & $\leftarrow$ & Dynamics of Gapoktan & 0.557 \\
Group coaching (X26) & $\leftarrow$ & Dynamics of Gapoktan & 0.458 \\
Assistance and counseling (X31) & $\leftarrow$ & Supporting factors of PUAP program & 0.460 \\
Availability of production facilities (X32) & $\leftarrow$ & Supporting factors of PUAP program & 0.477 \\
Access to market information (X33) & $\leftarrow$ & Supporting factors of PUAP program & 0.814 \\
Transportation facilities (X34) & $\leftarrow$ & Supporting factors of PUAP program & 0.892 \\
Knowledge (Y11) & $\leftarrow$ & Entrepreneurial behavior & 0.600 \\
Attitude (Y12) & $\leftarrow$ & Entrepreneurial behavior & 0.535 \\
Skill (Y13) & $\leftarrow$ & Entrepreneurial behavior & 0.582 \\
Increased income (Y21) & $\leftarrow$ & Business performance & 0.586 \\
Expansion of the marketing area (Y22) & $\leftarrow$ & Business performance & 0.656 \\
Competitive advantage (Y23) & $\leftarrow$ & Business performance & 0.687 \\
Business endurance (Y24) & $\leftarrow$ & Business performance & 0.615 \\
\hline
\end{tabular}

Table 5 shows that internal factor variables are formed by six indicators with experience as the strongest indicator with factor loading value of 0.633 . Then, Gapoktan structure is the strongest indicator that forms the dynamics of Gapoktan with loading factor value of 0.652 . The strongest indicator of the supporting factors of the PUAP program is the ease of transportation with loading factor of 0.892 . For the entrepreneurial behavior variable, knowledge is the strongest indicator with loading factor value of 0.600 . Lastly, the strongest indicator of business performance variables is a competitive advantage with factor loading 0.687.

\section{Structural model analysis}

Hypothesis testing was carried out to find out directly the relationship between variables (Table 6).

Table 6. The results of SEM analysis and hypothesis testing

\begin{tabular}{llccccc}
\hline & & S.E. & Std. Estimate & C.R. & P & Result \\
\hline Internal factors & $\rightarrow$ & 0.220 & 0.022 & 0.177 & 0.859 & Not significant \\
$\begin{array}{l}\text { Entrepreneurial } \\
\text { behavior }\end{array}$ & $\rightarrow \begin{array}{l}\text { Entrepreneurial } \\
\text { behavior }\end{array}$ & 0.263 & 0.341 & 2.183 & 0.029 & Significant \\
$\begin{array}{l}\text { Gapoktan of } \\
\begin{array}{l}\text { Supporting factors } \\
\text { of PUAP program }\end{array}\end{array}$ & $\rightarrow \begin{array}{l}\text { Entrepreneurial } \\
\text { behavior }\end{array}$ & 0.356 & 0.695 & 3.742 & 0.000 & Significant \\
$\begin{array}{l}\text { Entrepreneurial } \\
\text { behavior }\end{array}$ & $\rightarrow \begin{array}{l}\text { Business } \\
\text { performance }\end{array}$ & 0.208 & 0.764 & 4.075 & 0.000 & Significant \\
\hline
\end{tabular}




\section{Internal factors to entrepreneurial behavior}

The result of the first hypothesis testing indicates that the internal factors did not significantly influenced to entrepreneurial behavior, with $\mathrm{CR}$ value was 0.177 (CR <1.96) and the probability value was $0.859(\mathrm{P}>0.05)$. Education, experience, business scale, cosmopolitan, the motivation of farming and perception on farming had no effect on the entrepreneurial behavior of PUAP program recipient farmers in Pandawai. These are supported by Zainura et al. (2017) which found no evidence of a relationship between individual characteristic variables and entrepreneurial behavior. On the other hand, it stands in contrast to Dirlanudin (2010) and Nursiah et al. (2015) that stated internal factors had an effect on entrepreneurial behavior, in which the increasing internal factors of a person will increase the entrepreneurial behavior. The different result also found in Arnis et al. (2018) that showed individual factors can improve entrepreneurial behavior

Based on the standardized regression weight value in Table 5, it showed that experience indicator (X12) had the highest effect on internal factors with estimated value of 0.633 , while the lowest is motivation of farming with estimated value of 0.444 . Based on conditions in the field, the level of farmer experience is quite high, for the majority of farmers have more than fifteen years of farming experience. It was also found that farmers did not have strong motivation to become successful farmers and lacked the desire to excel one another. In contrast to the research conducted by Arnis et al. (2018), it was stated that the most dominant indicator that reflects the internal factors of salted fish entrepreneurs is motivation. Most of the farmers who received the PUAP program in Pandawai sub-district were subsistence farmers who had a farming orientation which tended only for fulfill their daily needs.

\section{The effects of the dynamics of Gapoktan on entrepreneurial behavior}

The second hypothesis that stated the dynamics of Gapoktan have a positive and significant effect on entrepreneurial behavior is supported by the result of this study. Based on SEM analysis seen in Table 6, the CR value of the effect of the dynamics of Gapoktan on entrepreneurial behavior is $2.183(\mathrm{CR}>1.96)$ and the probability value is $0.029(\mathrm{p}<0.05)$, which means that the dynamics of Gapoktan have a positive and significant effect on entrepreneurial behavior. In this study, empirical evidence shows that the entrepreneurial behavior of farmers will increase along with better dynamics of Gapoktan. On the contrary, the lower the dynamics of Gapoktanis, the lower entrepreneurial behavior of $P U A P$ program recipient farmers in Pandawai will be. These results support the findings by Priyanto (2005) that the environment of the organization positively influences the development of one's entrepreneurship. The role of farmer group organizations is to help farmers in improving the technique of farming, provision of production facilities and strengthening the bargaining position of farmers when selling farm produce.

According to Puspitaningsih et al. (2016), a group can be categorized as good dynamics if all elements in the group interact and act in accordance with their respective functions. Based on the standardized regression weight value, it can be seen that the structure of group indicator (X22) is the most influential indicator of the dynamics of Gapoktan with estimated value of 0.652 , while the group training indicator (X26) has the lowest effect with the estimated value of 0.458 (Table 5). The PUAP program recipient farmers were highly enthusiastic in Gapoktan organization because they needed the role of Gapoktan in their farming business. In the implementation of the PUAP program, empowering farmers through Gapoktan was carried out by training the farmers and providing production facilities that support the program (Dewi, 2016).

The effects of supporting factors of PUAP program on entrepreneurial behavior

The result of the third hypothesis testing, which states that the supporting factors of the PUAP program have a positive and significant effect on entrepreneurial behavior, is supported by the result of this study. This can be seen from the $\mathrm{CR}$ value of the effect of the supporting factors of the PUAP program on entrepreneurial behavior at 3.742 (CR> 1.96) and the probability value is 0.000 ( $\mathrm{p}<0.05$ ). This shows that the increasing supporting factor indicators of the PUAP program will improve farmers entrepreneurial behavior. Supports in intensive assistance and counseling, guaranteed availability of production facilities, availability of market information and ease of access to transportation are also needed by farmers to generate entrepreneurial motivation 
and behavior in their farming business during the implementation of the PUAP program. This findings in accordance with the research conducted by of Arisena et al. (2014), Zainura et al. (2017) and Amir et al. (2018) which states that the better the business climate, which is the external factor of farmers, the stronger the farmers' perspective on their entrepreneurial behavior is.

Based on the standardized regression weight value in Table 5, it can be seen that the ease of transportation indicator is the most influential indicator of the supporting factors of the PUAP program with the estimated value of 0.892 while the mentoring and extension indicators have the lowest effect with the estimated value of 0.460 . Transportation, in general, was very good, in terms of road access and the availability of adequate transportation facilities. The assistance and counseling carried out during the implementation of the PUAP program were considered to be inadequate to the extent that they did not play a significant role in the formation of entrepreneurial behavior of recipient farmers the PUAP program in Pandawai.

Based on SEM analysis seen in Table 6, among the examined causal relationships, the relationship between the supporting factors of the PUAP program on entrepreneurial behavior is the most influentially because the standard loading value is higher than the other causal relationships (Table 6). In addition, loading factor value had influence about 0.695 , wich shows that the relationship between the supporting factors of the PUAP program and entrepreneurial behavior is positive, where one percent of increasing in the supporting factors of the PUAP program will increase of 69.5 percent in the entreoreneurial behavior of PUAP program recipient farmers.

\section{The effects of entrepreneurial behavior on business performance}

The fourth hypothesis which states that entrepreneurial behavior has a positive and significant effect on business performance is supported by the result of this study. Based on SEM analysis, it can be seen that the CR value of the effect of entrepreneurial behavior is 4.075 $(\mathrm{CR}>1.96)$ and the probability value is $0.000(\mathrm{p}$ $<0.05$ ). These results indicate that entrepreneurial behavior has a positive and significant effect on business performance. The significant and positive sign on the standard coefficient shows that the increasing of entrepreneurial behavior of PUAP programs recipient farmers will improve their farming business performance. These findings provide empirical evidence on the statement of Arisena, et al. (2014), Nursiah et al. (2015) and Darmadji, (2016) that entrepreneurship has a direct effect on business performance. The entrepreneurial behavior that arises in a farmer, either in terms of knowledge, attitudes and skills, will affect the performance of the farming business (Dirlanudin, 2010). Similarly, the finding support Fayaz et al. (2016), Arnis et al., (2018) and Konte et al. (2019) that stated entrepreneurial behavior significantly improve agricultural business performance; thus it is very important to maximize the potential and capability of farmers in entrepreneurship in order to achieve higher standard of business performance. The right strategy needs to be formulated by researchers and policymakers to achieve higher standard in agricultural business performance.

Competitive advantage (Y23) contributes the largest estimated value to farming performance, which stands at 0.687 and the lowest was increase in income (Y21) with an estimated value of 0.586 (Table 5). It was also founded that the increased competitive advantage of farming business was not always followed by increases in their income due to the low level of their farming production. Because of their limited capital, farmers unable to increase their business scale, which ultimately leads to a stagnant level of production, making it difficult to increase the income from the farming business they work on (Priyanto, 2006).

\section{CONCLUSIONS}

Based on data analysis and discussion it can be concluded that (1) The internal factors of farmers have a positive but not significant effect on entrepreneurial behavior. This means that education, experience, business scale, cosmopolitan, motivation and perception on farming do not affect farmers entrepreneurial behavior who received PUAP programs. Meanwhile, the dynamics of Gapoktan have a positive and significant effect on entrepreneurial behavior. Then, the supporting factors of the PUAP programs also have a positive and significant effect on entrepreneurial behavior. This happens because the supports provided by the government on the implementation of the 
PUAP program had been considered sufficient and able to support the entrepreneurial behavior. (2) Entrepreneurial behavior has a positive and significant effect on farmers business performance who receive PUAP program. Therefore, farmers entrepreneurial behavior has a highly significant role in improving farming performance on the implementation of the PUAP program, so that their knowledge, attitudes and entrepreneurial skills can influence the performance of their business.

It can be recommended for government to continue to develop entrepreneurial behavior in implementing agricultural programs because it plays a determining role in farmers' business performance. Therefore, greater attention should be focused on strengthening and improving farmers internal management, along with improving government assistance through Gapoktan and increasing provision for agricultural supporting facilities, such as access to production, market information, technology and marketing strategies complemented by strengthening of human resources. The government can conduct trainings aimed to shift farmers orientation from only fulfilling their daily needs to be more business-oriented.

\section{REFERENCES}

Amir, R. M., Burhanuddin, B., \& Priatna, W. B. (2018). The Effect of Individual, Environmental and Entrepreneurial Behavior Factors on Business Performance of Cassava SMEs Agroindustry in Padang City. Indonesian Journal of Business and Entrepreneurship, 4(1), 1-10. https://doi.org/ 10.17358/ijbe.4.1.1

Arisena, G. M. K., Mustadjab, M. M., Setiawan, B., \& Koestiono, D. (2014). The Influence of Environment and Entrepreneurship Factors toward the Farming Performance (Case on Manager Farmers of Cloves Plantation in Buleleng Regency, Bali Province). Journal of Economics and Sustainable Development, 5(9), 49-56. Retrieved from https:// iiste.org/Journals/index.php/JEDS/article/vie w/13212/13326

Arnis, N., Baga, L. M., \& Burhanuddin. (2018). The effect of Entrepreurial Behavior on Salted Fish Business Performance at Muara Angke. Indonesian Journal of Business and
Entrepreneurship, 4(3), 217-226. https:// doi.org/10.17358/ijbe.4.3.217

Badan Pelaksana Penyuluhan Pertanian Perikanan dan Kehutanan Sumba Timur, [BP4K]. (2016). Laporan Pengelolaan Bantuan Langsung Mandiri Program Usaha Agribisnis Perdesaan (BLM-PUAP) 2008-2015. Sumba Timur.

Badan Pusat Statistik, [BPS]. (2018). Profil Kemiskinan di Indonesia Maret 2018. Retrieved December 16, 2018, from https://www.bps.go.id/pressrelease/2018/07/1 6/1483/persentase-penduduk-miskin-maret2018-turun-menjadi-9-82-persen.html.

Bahri, S., \& Zamzam, F. (2014). Model Penelitian Kuantitatif Berbasis SEM-AMOS (1st ed.). Yogyakarta: Deepublish Publisher.

Balai Penyuluhan Pertanian Perikanan dan Kehutanan Pandawai, [BP3K Pandawai]. (2016). Laporan Program Pengembangan Agribisnis Perdesaan (PUAP) OktoberDesember 2016. Pandawai.

Caesarion, R., Pandjaitan, N. H., \& Syamsun, M. (2013). Efektivitas Program Pengembangan Usaha Agribisnis Perdesaan di Kabupaten Lampung Selatan. Jurnal Manajemen IKM, 8(2), 199-209. https://doi.org/10.29244/199209

Darmadji. (2016). Entrepreneurship as New Approach to Support National Agriculture Development Program to Go Self Sufficient Food. Agriculture and Agricultural Science Procedia, 9, 72-82. https://doi.org/10.1016/ j.aaspro.2016.02.128

Delmar, F. (1996). Entrepreneurial Behaviour and Business Performance (Doctoral Thesis). Stockholm School of Economics. Retrieved from http://citeseerx.ist.psu.edu/viewdoc/ download?doi=10.1.1.463.6117\&rep=rep1\&t ype $=$ pdf

Dewi, S. (2016). Dampak Pengembangan Manajemen Usaha Gabungan Kelompok Tani (Gapoktan) "Sejahtera" pada Tingkat Kinerja Petani Penerima Program Pengembangan Usaha Agrobisnis Perdesaan (PUAP) di Desa Mertani Kecamatan Karanggeneng Kabupaten Lamongan. Jurnal Kebijakan Dan Manajemen Publik, 4(4). Retrieved from http://journal. unair.ac.id/KMP@dampakpengembangan- 
manajemen-usaha-gabungan-kelompok-taniarticle-10948-media-138-category-.html

Dirlanudin. (2010). Perilaku Wirausaha dan Keberdayaan Pengusaha Kecil Industri Agro: Kasus di Kabupaten Serang Provinsi Banten (Doctoral Thesis). Institut Pertanian Bogor. Retrieved from https://repository.ipb.ac.id/ bitstream/handle/123456789/55034/2010dir.p df? sequence $=3 \&$ is Allowed $=y$

Dumasari. (2014). Kewirausahaan Petani Dalam Pengelolaan Bisnis Mikro di Pedesaan. Jurnal Inovasi Dan Kewirausahaan, 3(3), 196-202. https://doi.org/10.20885/ajie.vol3.iss3.art4

Fayaz, S., Gopal, P. V. S., \& Prasad, S. V. (2016). Impact of Entrepreneurial Behaviour on Farming Performance of Cotton Growers, 16(2), 37-42. Retrieved from https:// seea.org.in/irjee/upload/v16208.pdf

Ferdinand, A. (2014). Structural Equation Model dalam Manajemen: Pedoman Penelitian untuk Penulisan Skripsi, Tesis dan Disertasi Ilmu Manajemen (4th ed.). Semarang: Badan Penerbit Universitas Diponegoro.

Firdaus, N. (2014). Pengentasan Kemiskinan melalui Pendekatan Kewirausahaan Sosial. Jurnal Ekonomi Dan Pembangunan, 22(1), 55-67. Retrieved from http://jurnalekonomi. lipi.go.id/index.php/JEP/article/view/29/13

Ghozali, I. (2017). Model Persamaan Struktural: Konsep dan Aplikasi dengan Program AMOS 24-Update Bayesian SEM. Semarang: Badan Penerbit Universitas Diponegoro.

Hafinuddin, M., Mulyaningsih, A., \& Salampessy, Y. L. A. (2013). Hubungan Dinamika Gapoktan dengan Keberhasilan Program Pengembangan Usaha Agribisnis Perdesaan. Jurnal Ilmu Pertanian Dan Perikanan, 2(2), 93-97. Retrieved from https://anzdoc.com/hubungan-dinamikagapoktan-dengan-keberhasilan-programpenge.html

Haryono, S. (2017). Metode Penelitian SEM untuk Penelitian Manajemen: AMOS, LISREL,PLS. Jakarta: PT. Luxima Metro Media.

Hermawan, H., Suharno, \& Fariyanti, A. (2015). Peran Program Pengembangan Usaha Agribisnis Perdesaan terhadap Kinerja
Gapoktan dan Pendapatan Usahatani padi di Kabupaten Subang. Jurnal Pengkajian Dan Pengembangan Teknologi Pertanian, 18(1), 1-10. https://doi.org/10.21082/jpptp.v18n1. 2015.p\%25p

Kementerian Pertanian, (KEMENTAN). (2008). Peraturan Menteri Pertanian Nomor: 16/Permentan/OT.140/2/2008 tentang Pedoman Umum Pengembangan Usaha Agribisnis Perdesaan (PUAP). Jakarta. Retrieved from http://perundangan.pertanian. go.id/admin/file/Permentan-16-08.pdf

Konte, M. S., Ayuya, O. I., \& Gathungu, E. (2019). Effect of Entrepreneurial Behaviour on Farm Performance among Small-scale Farmers: Case of Niono Zone, Mali. Advances in Agricultural Science, 7(01), 24-39. Retrieved from http://aaasjournal.org/ submission/index.php/aaas/article/view/116/6 5

Naminse, E. Y., \& Zhuang, J. (2018). Does farmer entrepreneurship alleviate rural poverty in China? Evidence from Guangxi Province. Journal PLoS One, 13(3), 1-18. https:// doi.org/10.1371/journal.pone.0194912

Nindatu, P. I. (2012). Efektivitas Komunikasi pada Program Pengembangan Usaha Agribisnis Perdesaan (PUAP) di Kabupaten Halmahera Barat (Thesis). Institut Pertanian Bogor. Retrieved from https://repository. ipb.ac.id/bitstream/handle/123456789/59393/ 2012pin.pdf?sequence $=1 \&$ isAllowed $=y$

Nugroho, A. D., Waluyati, L. R., \& Jamhari. (2018). Evaluasi Program Pemberdayaan Usaha Agribisnis Perdesaan (PUAP) Provinsi Daerah Istimewa Yogyakarta. Jurnal Kawistara, 8(2), 111-212. https://doi.org/ 10.22146/kawistara.32086

Nursiah, T., Kusnadi, N., \& Burhanuddin. (2015). Perilaku Kewirausahaan pada Usaha Mikro Kecil (UMK) Tempe di Bogor Jawa Barat. Jurnal Agribisnis Indonesia, 3(2), 145-158. https://doi.org/10.29244/jai.2015.3.2.145-158

Priyanto, S. H. (2005). Model Hubungan Lingkungan Eksternal-KewirausahaanKinerja: Kasus di Usahatani Tembakau. Jurnal Bisnis Strategi, 14(1), 52-69. Retrieved from https://ejournal.undip.ac.id/index.php/jbs/artic le/view/14391/10985 
Priyanto, S. H. (2006). A Structural Model of Business Performance: An Empirical Study on Tobacco Farmers. Gadjah Mada International Journal of Business, 8(1), 103-134. Retrieved from https://jurnal.ugm.ac.id/gamaijb/article/ view/5622/4595

Puspitaningsih, O. S., Utami, B. W., \& Wijianto, A. (2016). Partisipasi Kelompok Tani dalam Mendukung Program-Program Pertanian Berkelanjutan di Kecamatan Puring, Kabupaten Kebumen (Studi Komparasi Kelompok Tani Kelas Lanjut dan Pemula). Caraka Tani: Journal of Sustainable Agriculture, 31(2), 79-85. https://doi.org/ 10.20961/carakatani.v31i2.11950

Setiaji, H., \& Waridin. (2014). Dampak Program Pengembangan Usaha Agribisnis Perdesaan terhadap Pendapatan Anggota Gabungan Kelompok Tani. Diponegoro Journal of Economics, 3(1), 1-9. Retrieved from https://ejournal3.undip.ac.id/index.php/jme/ar ticle/view/5315

Sugiyono. (2013). Metode Penelitian Kombinasi (Mixed Methods). Bandung: Penerbit Alfabeta.
Supardi, P. N., Susrusa, K. B., \& Budiasa, I. W. (2015). Tingkat Keberhasilan Program Pengembangan Usaha Agribisnis Perdesaan di Kabupaten Ende Provinsi Nusa Tenggara Timur. Jurnal Manajemen Agribisnis, 3(2), 121-133. Retrieved from https://ojs.unud. ac.id/index.php/agribisnis/article/view/17099

Ximenes, T. (2014). The Influence of Personal and Environmental Factors on Business StartUps: A Case Study in the District of Dili. Journal Of School of Business, University of the Thai Chamber of Commerce, 8, 1-18. Retrieved from http://utcc2.utcc.ac.th/ utccijbe/_uploads/InProcess/201412/The Influence of Personal and Environmental Factors on Business Start_Ups.pdf

Zainura, U., Kusnadi, N., \& Burhanuddin. (2017). Pengaruh Perilaku Kewirausahaan terhadap Kinerja Usahatani Kopi Arabika Gayo di Kabupaten Bener Meriah Provinsi Aceh. Economicus: Jurnal Ekonomi Dan Manajemen, 8(1), 54-66. Retrieved from http://ejournal.dewantara.ac.id/index.php/eco nomicus/article/view/11/11 